\title{
The potential utility of B cell-directed biologic therapy in autoimmune diseases
}

\author{
D. G. Arkfeld
}

Received: 13 August 2007 / Accepted: 28 September 2007 / Published online: 24 October 2007

(C) Springer-Verlag 2007

\begin{abstract}
Increasing awareness of the importance of aberrant $\mathrm{B}$ cell regulation in autoimmunity has driven the clinical development of novel B cell-directed biologic therapies with the potential to treat a range of autoimmune disorders. The first of these drugs-rituximab, a chimeric monoclonal antibody against the B cell-specific surface marker CD20was recently approved for treating rheumatoid arthritis in patients with an inadequate response to other biologic therapies. The aim of this review is to discuss the potential use of rituximab in the management of other autoimmune disorders. Results from early phase clinical trials indicate that rituximab may provide clinical benefit in systemic lupus erythematosus, Sjögren's syndrome, vasculitis, and thrombocytopenic purpura. Numerous case reports and several small pilot studies have also been published reporting the use of rituximab in conditions such as myositis, antiphospholipid syndrome, Still's disease, and multiple sclerosis. In general, the results from these preliminary studies encourage further testing of rituximab therapy in formalized clinical trials. Based on results published to date, it is concluded that rituximab, together with other B cell-directed therapies currently under clinical development, is likely to provide an important new treatment option for a number of these difficult-to-treat autoimmune disorders.
\end{abstract}

Keywords Biologic therapies - B-lymphocytes . CD20 - Lupus · Rituximab · Sjögren's syndrome · Thrombocytopenic purpura $\cdot$ Vasculitis

D. G. Arkfeld ( $\square)$

Division of Rheumatology, Keck School of Medicine, University of Southern California, HMR 711, 2011 Zonal Avenue, Los Angeles, CA 90033, USA e-mail: arkfeld@usc.edu

\section{Background}

Autoimmunity is widely believed to be fundamental to the development and progression of many rheumatic diseases-rheumatoid arthritis (RA) and systemic lupus erythematosus (SLE) being the best-known examples. The function of B cells in autoimmunity is still not fully understood, although evidence is mounting that they play an essential role in the process. In addition to their well-known function in synthesizing antibodies, B cells act in antigen presentation and as critical regulators of the development and function of $\mathrm{T}$ cells [21]. B cells are also the source of rheumatoid factor, levels of which are strongly correlated with disease severity in RA [103]. These and other lines of evidence provided the rationale for testing whether B cell depletion would be an effective strategy for treating rheumatic diseases. The availability of rituximab (RITUXAN ${ }^{\circledR}$; Genentech/Biogen-IDEC, South San Francisco, CA, USA), a genetically engineered monoclonal antibody directed against the B cell-specific antigen CD20 [60], enabled this hypothesis to be tested. The first results, demonstrating sustained clinical responses coupled with B cell depletion in 5 RA patients treated with rituximab [30], ignited intense interest in the wider potential of B cell depletion therapy in autoimmune diseases.

A full-scale clinical trial program led to the approval of rituximab in 2006 for the treatment of RA in patients with an inadequate response to anti-tumour necrosis factor (TNF) therapy. A number of other B cell-directed agents are currently in clinical development. Among the most advanced is epratuzumab, a humanized monoclonal antibody directed against CD22, another B cell-specific marker [90]. Epratuzumab has been tested in patients with Sjögren's syndrome (SS) [89] and results were published recently of an open-label clinical trial involving patients 
with SLE [29]. Another strategy under investigation is the neutralization of B cell survival factors. BAFF (also known as B lymphocyte stimulator, BLyS) is essential for the survival of $\mathrm{B}$ cells and is involved in many other aspects of $\mathrm{B}$ cell biology, including germinal center maintenance, isotype switching, and regulation of B cell-specific markers [48]. Belimumab is an anti-BAFF monoclonal antibody that has reached Phase II trials in SLE and RA [27], while atacicept (previously known as TACI-Ig), a recombinant fusion protein that neutralizes both BAFF and APRIL (a related B cell survival factor) [41], has undergone Phase I evaluation in SLE. A more in-depth review was published recently of current B cell-targeted approaches that are being developed to treat autoimmune disorders [31].

The aim of this review is to discuss the potential utility of B cell-directed therapy in the management of autoimmune disorders. As the first of these agents to be approved for clinical use, rituximab will be the focus of this article. In addition, since several excellent reviews have been published recently covering the use of rituximab in RA [25, 31, 58], this review will discuss results from the clinical testing of rituximab in autoimmune disorders other than RA. Information from case reports, clinical trials, and other studies was gathered from a search of the Medline database up to and including June 2007.

\section{Clinical use of rituximab}

Rituximab has been tested in a wide range of autoimmune conditions, with clinical trials being most advanced in SLE and SS. A summary of the published clinical data in these and other autoimmune disorders is presented in Table 1.

\section{Systemic lupus erythematosus}

Traditional treatments for SLE include nonsteroidal antiinflammatory drugs, antimalarials, corticosteroids, methotrexate, mycophenylate, and cytotoxic drugs such as cyclophosphamide (often in combination). However, these therapies are associated with many potential side effects and are usually only partially effective in the long term [46]. The wide body of evidence indicating that B cells play a central role in the etiopathology of SLE has focused attention on the potential benefits of rituximab and other B celltargeted therapies in the disease [33, 57, 78].

Individual case reports and case series, together with encouraging results from early phase clinical trials, indicate that rituximab is likely to provide significant clinical benefit for at least a subset of SLE patients. For example, in a doseescalation study involving 17 patients, significant improvements in the systemic lupus activity measure (SLAM) score were observed in those patients (11/17) who achieved con- comitant profound B cell depletion; efficacy persisted for 12 months and no significant adverse events were reported [59]. Analysis of some of the patients in this trial revealed that clinical response to rituximab correlated closely with the Fc $\gamma \mathrm{I}$ IIa genotype of individual patients [6], as observed previously in studies involving the rituximab responses of patients with follicular lymphoma [96]. In another open-label study, 23/24 patients achieved depletion of B cells following treatment with rituximab (two $1,000 \mathrm{mg}$ infusions of rituximab separated by 2 weeks); depletion lasted for 3-8 months-except in 1 individual, who remained depleted after 4 years [55]. Clinical improvements observed in this study occurred in each of the 8 organs/systems assessed using the British Isles Lupus Assessment Group (BILAG) system. A recent update from the same group - covering a total of 41 patients with a mean (range) follow-up period of 37 (6-79) months-reported that one-third of patients remained well following B cell depletion, without the need for immunosuppressive agents [64]. Thirteen patients had been re-treated with rituximab. Three serious adverse events (1 pneumococcal sepsis, 1 severe serum sickness-like reaction, and 1 seizure related to hyponatremia) and 2 deaths (1 involving varicella pneumonitis and the other involving pancarditis) had occurred in this cohort over the 7-year observation period.

In another trial involving patients with active or refractory SLE, with a follow-up period of 2 years, all 11 patients in the study responded to a single course of rituximab, with 6 achieving a full response and 5 a partial response; although relapse was common (64\%), re-treatment was rapidly effective [85].

In a recently reported case series of six patients with aggressive refractory SLE, rituximab therapy (doses of rituximab and use of combination drugs varied between patients) resulted in partial clinical improvements in five cases [40]. Rituximab has also shown effectiveness in pilot studies involving patients with the common severe complication lupus nephritis [42, 84, 95] and in patients with refractory SLE involving the central nervous system [92].

Although most studies to date indicate that B cell depletion therapy is likely to be useful in SLE, the variability of responses to rituximab therapy observed in SLE trials published to date remains to be explained. Ongoing Phase II/III randomized controlled trials should provide some insight into this question. In addition, although the overall tolerability of rituximab in SLE appears to be good, the Food and Drug Administration recently issued an alert concerning two spontaneous fatal cases of progressive multifocal leukoencephalopathy (PML) due to JC polyomavirus reactivation in two patients with SLE who had received rituximab therapy [38]. It is unclear whether these cases were related to rituximab treatment, since only two cases have been reported and PML has also been reported in >20 SLE patients not treated with rituximab. 


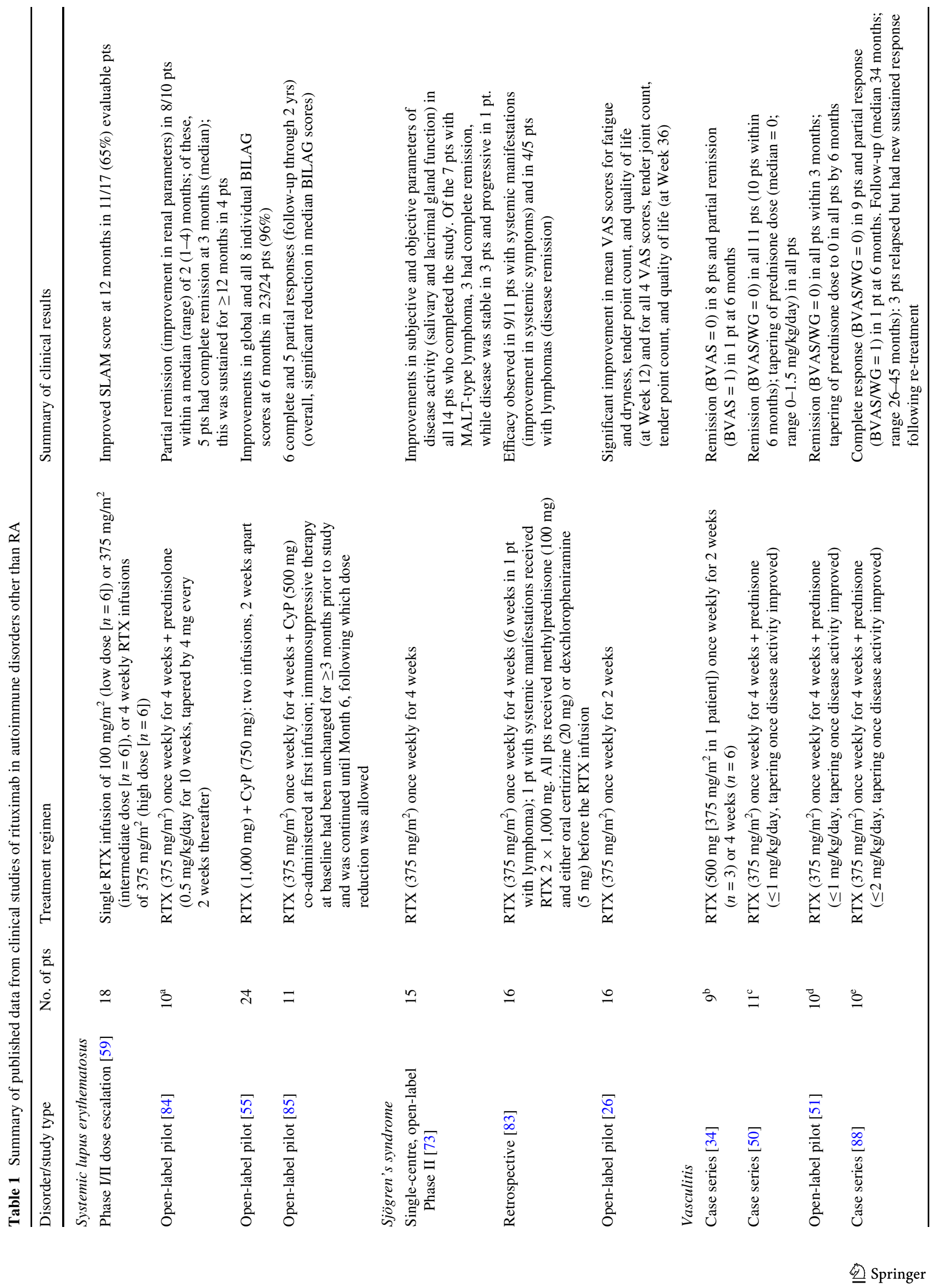




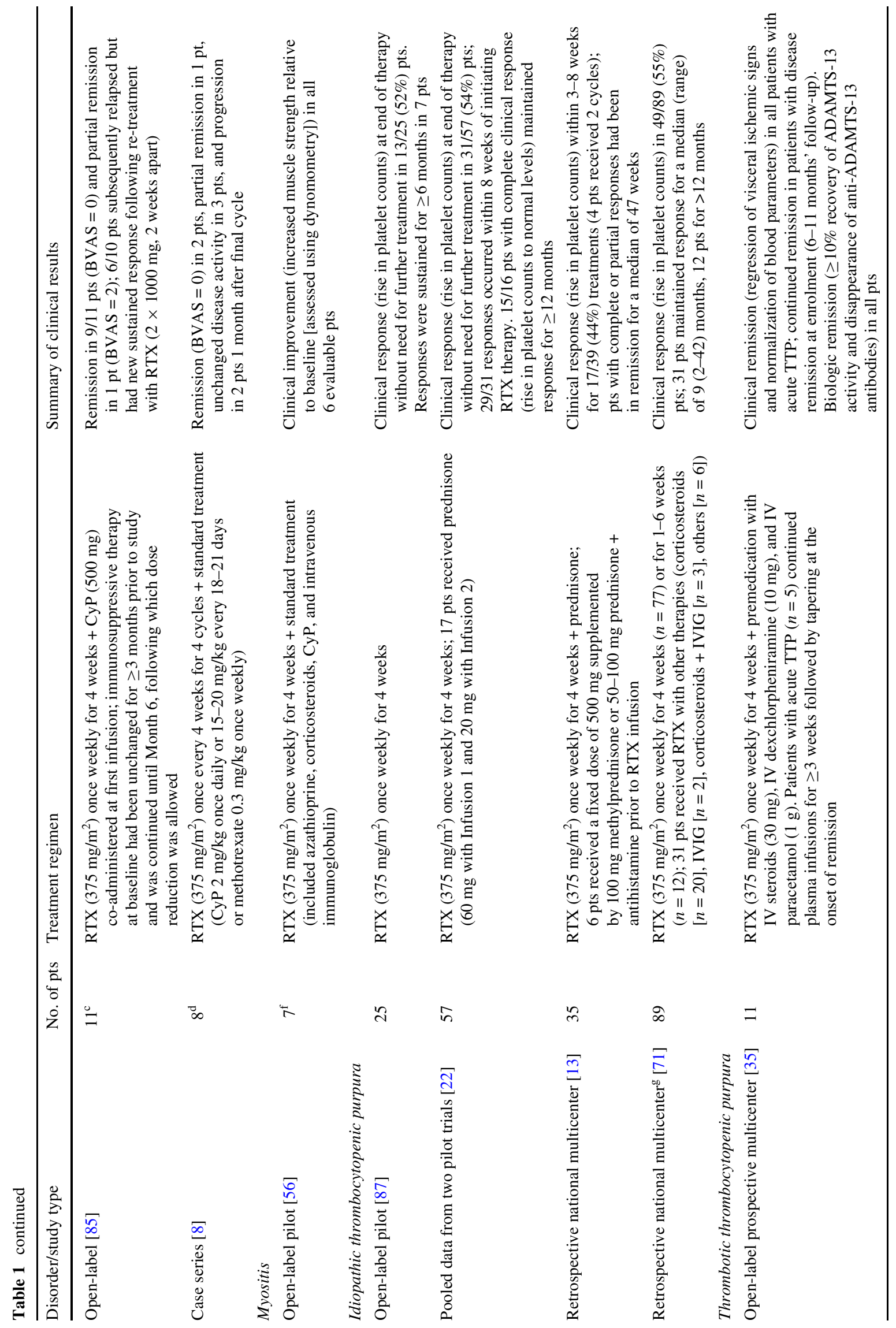




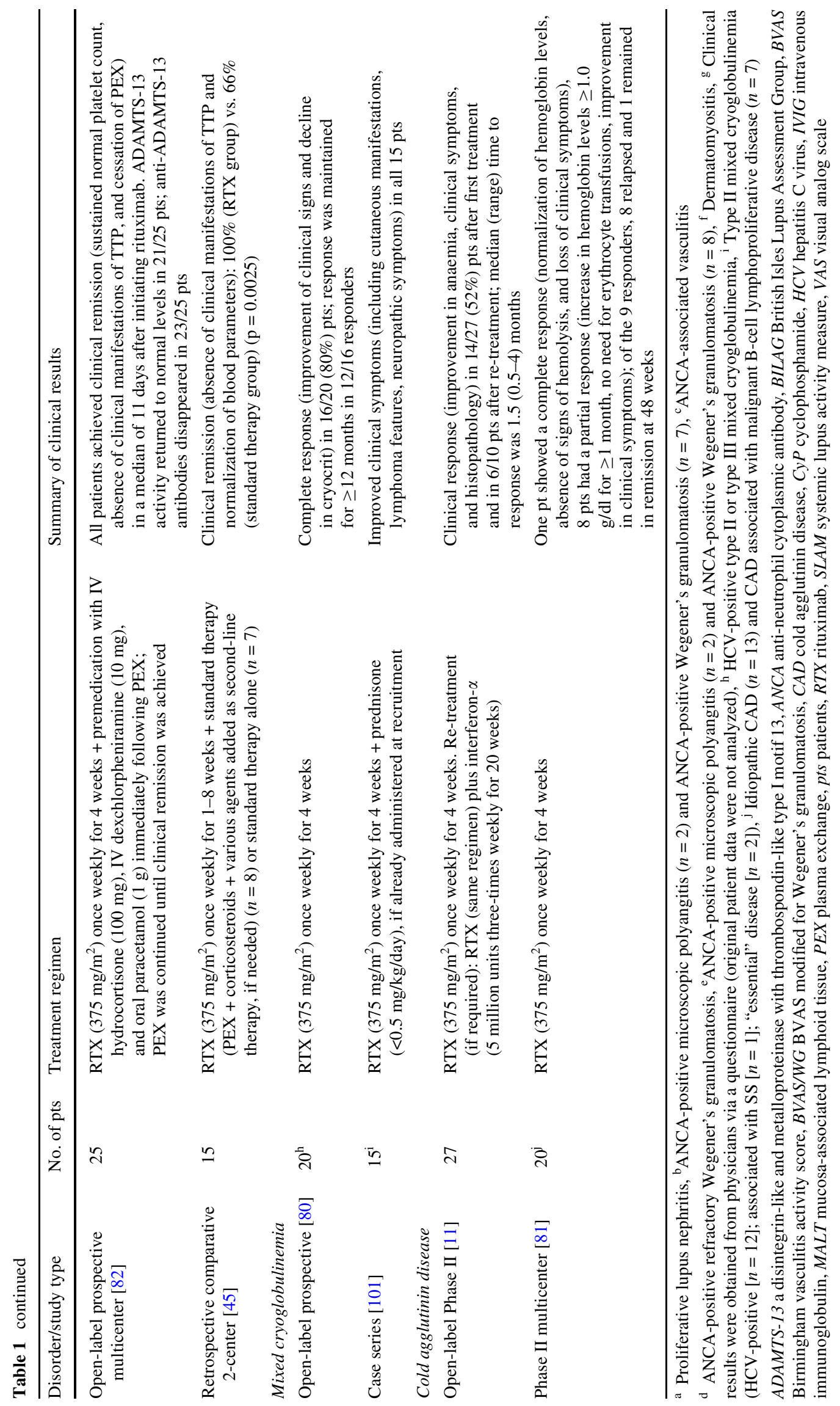




\section{Sjögren's syndrome}

Sjögren's syndrome is a chronic autoimmune disorder of the exocrine glands affecting approximately $1 \%$ of the adult US population. The syndrome often occurs in the presence of another autoimmune disorder such as RA or SLE [37]. The etiopathology of SS is not fully understood; however, disturbances in B cell biology are considered to play an important role [43].

A number of case reports and pilot studies have been published that describe the successful treatment of SS with rituximab [2, 73, 76, 93]. In a recent trial involving 16 female patients with systemic complications of primary SS, rituximab therapy led to $\mathrm{B}$ cell depletion and decreased levels of various B cell markers; with a median follow-up period of 14.5 months, clinical efficacy was observed in $4 / 5$ patients with lymphomas and in 9/11 patients with other systemic manifestations [83].

Another recent study investigated the effects of rituximab (two infusions of $375 \mathrm{mg} / \mathrm{m}^{2}$ separated by 1 week) in 16 patients with primary SS [26]. Rituximab therapy, which was administered using a slow initial rate of infusion without steroid premedication, was well tolerated and overall improvements were observed in subjective parameters of disease activity and in quality of life after both 12 and 36 weeks' follow-up.

Results were presented recently from the first doubleblind, randomized, controlled study of rituximab in SS [24]. In this 20-patient pilot study, subjects received either rituximab (two $1,000 \mathrm{mg}$ infusions separated by 2 weeks) or placebo. Although patient responses were highly variable and there was a marked placebo effect, a higher proportion of patients in the rituximab group achieved improvement in fatigue (the primary efficacy endpoint) than in the placebo group ( 48 vs. $20 \%$ ); this difference was not statistically significant. Significantly greater improvements with rituximab over placebo in the social functioning aspect of the quality of life assessment were also noted.

\section{Vasculitis}

Vasculitis refers to a collection of rare inflammatory diseases that involve the blood vessel walls and surrounding interstitium. A subset of these diseases, including Wegener's granulomatosis (WG), microscopic polyangitis, and Churg-Strauss syndrome, is characterized by the presence of anti-neutrophil cytoplasmic antibodies (ANCAs) [97]. The mainstay of current therapies in vasculitis involves glucocorticoids, cyclophosphamide, and-more recently-methotrexate and azathioprine [54]. However, these approaches are not always effective and are often limited by significant toxicity. B cells have been implicated in the pathogenesis of ANCA-associated vasculitis [20], indicating that rituximab may be an effective treatment option.

In addition to a number of individual case reports, results have been published recently from several small open-label trials of rituximab in vasculitis. In a report of a series of nine individual cases of ANCA-positive vasculitis resistant to conventional therapy in which rituximab therapy was attempted, eight patients achieved complete responses, while the other patient showed a partial response [34]. Keogh and colleagues have conducted small, prospective, open-label trials in both ANCA-associated vasculitis and WG. The vasculitis trial involved 11 patients whose disease was either refractory to cyclophosphamide or in whom cyclophosphamide was contraindicated [50]. Following infusions with rituximab, circulating B cells became undetectable in all patients and ANCA titers decreased significantly. Clinical remission was achieved in all patients and was maintained while B cells were undetectable. In ten patients with refractory WG treated with prednisone $(1 \mathrm{mg} /$ $\mathrm{kg} /$ day) plus rituximab (four consecutive weekly infusions of $375 \mathrm{mg} / \mathrm{m}^{2}$ ) [51], therapy was well tolerated and-after 3 months-all patients had achieved clinical remission (reduction in disease activity score to 0 ); in addition, all patients were able to stop glucocorticoids by 6 months. Following the recurrence of raised ANCA titers, five patients in the trial were successfully re-treated with rituximab. Results were also recently published of long-term followup of ten patients with ANCA-associated vasculitis who had been treated with rituximab [88]: patients had received four consecutive weekly doses of rituximab $\left(375 \mathrm{mg} / \mathrm{m}^{2}\right)$ and all experienced rapid clinical improvement at 6 months. Although three patients subsequently relapsed, re-treatment was effective. In addition, ANCA titers decreased significantly in all patients. Of 11 patients with refractory ANCA-associated vasculitis who were treated with rituximab in another recently published pilot study, 10 showed either complete or partial responses to a course of rituximab together with a single dose of cyclophosphamide [85].

In contrast to the above findings, one recent study found that rituximab was less effective in a cohort of eight patients with refractory WG [8]. In this trial, rituximab was given every fourth week. Interestingly, all patients in this study had particular granulomatous manifestations, consisting of retro-orbital granulomata $(n=5)$, nodules of the lungs $(n=1)$, and subglottic stenosis $(n=2)$. Although three patients experienced some clinical improvement, ANCA titers were not affected by rituximab therapy (except in a single patient). A smaller Norwegian study had also previously found only temporary responses to rituximab in three patients with WG, two of whom had granulomatous masses [68]. 
In a recent review of published studies in this area, it was concluded that rituximab may be an effective treatment in patients with refractory ANCA-associated vasculitis (with the probable exception of WG patients with retro-orbital granulomas, who tended to be less responsive to rituximab therapy) [98]. Since then, however, case reports have appeared describing the successful use of rituximab in patients with granulomatous involvement [79, 91]. In addition, results from a recent case series of eight WG patients indicated that, while vasculitis symptoms tended to disappear relatively quickly, granulomatous manifestations usually regressed more slowly (sometimes over several months) [14].

With regard to other forms of ANCA-associated vasculitis, two individual case reports have been published recently detailing the successful treatment of ChurgStrauss syndrome with rituximab $[49,52]$.

Thrombocytopenic purpura and other hematologic disorders

A number of autoimmune disorders of hemostasis, most notably idiopathic thrombocytopenic purpura (ITP) and thrombotic thrombocytopenic purpura (TTP), have been examined for their potential responsiveness to rituximab in several small trials.

In a study involving a cohort of 25 patients with chronic ITP that had proved resistant to conventional therapies [87], patients received weekly rituximab at a dose of $375 \mathrm{mg} / \mathrm{m}^{2}$ for 4 weeks. The overall response rate (comprising those with complete, partial, and minor responses) was 52\%; responses were sustained for at least 6 months in 7 patients. Complete and partial responses were associated with rapid normalization of platelet concentrations. A similar initial response rate $(54 \%)$ was reported from a larger follow-up trial involving 57 patients; sustained responses were observed in $32 \%$ of the study participants [22]. Other reports include a multicenter trial in 35 adults with refractory ITP conducted in Denmark, which resulted in a $44 \%$ overall success rate based on predefined rises in platelet concentrations [13]. An indirect retrospective survey of findings from 89 ITP patients treated at multiple centers in Spain indicated that rituximab therapy led to sustained responses in $35 \%$ of patients with a median follow-up of 9 months (range 2-42 months) [71].

A review was published recently of the clinical outcomes of patients with chronic ITP who were re-treated with rituximab following an initial response to therapy [72]. All 9 second responses recorded in this report were classified as complete. An interesting additional finding was the higher female:male ratio of the nine re-treated patients compared with the population of patients originally treated across the published studies identified, suggesting that female ITP patients are more likely than male patients to respond to rituximab therapy. In a recently published letter, early administration of rituximab was reported to be associated with a higher response rate in chronic ITP [102].

The efficacy and safety of rituximab in adults with ITP were the subject of a recently published systematic review [9]. Based on 19 reports (313 patients) deemed eligible for the analysis up to April 2006, rituximab therapy was associated with mean complete response (platelet count $>150 \times 10^{9}$ cells/l) and overall response (platelet count $>50 \times 10^{9}$ cells/1) rates of 44 and $63 \%$, respectively. Significant toxicities including death occurred in $3 \%$ of included cases, although the deaths were not necessarily attributable to rituximab therapy. The authors noted the lack of randomized controlled studies of rituximab therapy in ITP.

A number of studies have also been conducted in patients with refractory or relapsing TTP. In addition to several case reports and small case series $[3,17,69,70,74$, 99], results from the first prospective trial have been published [35]. This study recruited 11 patients ( 6 enrolled during an acute refractory phase and 5 during a remission phase); following rituximab therapy $\left(375 \mathrm{mg} / \mathrm{m}^{2}\right.$ once weekly for 4 weeks), clinical remission was observed in all 6 acute cases, while all 5 patients enrolled during remission remained in clinical remission during the 6-11 month follow-up period. Biologic remission (disappearance of antiADAMTS-13 [a disintegrin and metalloproteinase with thrombospondin motif 13] antibodies, which occur in the great majority of patients with acquired TTP [75]) was achieved in all patients 7-24 weeks after the final rituximab infusion.

Another more recent study involved 25 patients with acute refractory/relapsing idiopathic TTP, who were given rituximab in conjunction with plasma exchange (PEX) because of progressive clinical disease [82]. It was reported that all 25 patients in this trial achieved complete clinical and laboratory remission (sustained normal platelet count, absence of clinical manifestations of TTP, and cessation of PEX) in a median of 11 days following the initiation of rituximab therapy. Restoration of ADAMTS-13 activity and disappearance of anti-ADAMTS antibodies occurred in the vast majority of cases. At the time of publication, it was stated that none of the patients had clinically relapsed, with a median (range) follow-up of 10 (1-33) months.

In another recent retrospective study, the clinical outcome of patients who had received rituximab $\left(375 \mathrm{mg} / \mathrm{m}^{2}\right.$ once weekly for a maximum of 8 weeks) together with standard therapy (PEX + corticosteroids) was compared with that of patients who had received standard therapy alone [45]. The remission rate in the rituximab group was significantly greater than that observed in the standard therapy group (100 vs. 66\%; $P=0.0025)$. Interestingly, all 
three of the TTP studies described above reported good tolerability to rituximab therapy.

There have also been sporadic case reports describing the successful use of rituximab in a number of other rare hematologic disorders, including Evans' syndrome [61, 65], mixed type II cryoglobulinemia [15, 80, 101], and cold agglutinin disease $[11,81]$. In addition, we have recently reported on the successful use of rituximab in RA patients with life-threatening hemorrhage due to the presence of Factor VIII inhibitor [67]. By contrast, a case report describing the failure of rituximab therapy in a hemophiliac patient with Factor VIII inhibitor has also been published [18]. A recent analysis of published case reports of patients with acquired antibodies to Factor VIII indicated that rituximab therapy was associated with a similar rate of clinical remission (approximately 80\%) compared with the standard treatment modality (cyclophosphamide + prednisolone) [86].

\section{Myositis}

Myositis comprises a group of inflammatory myopathies, of which polymyositis, dermatomyositis, and inclusion body myositis are the best defined clinically. The etiopathologies of this group of diseases are currently poorly understood, although autoimmunity is thought to play an important role [19].

The aim of a recent open-label pilot study involving seven patients with dermatomyositis was to test the hypothesis that B cells play a critical role in this disease [56]. The results of this trial, in which patients received four infusions of rituximab $\left(375 \mathrm{mg} / \mathrm{m}^{2}\right)$ at weekly intervals, showed that rituximab therapy was well tolerated and led to significant clinical improvements in the six evaluable patients who completed 1 year of follow-up. A number of other small pilot studies and case reports have also appeared recently detailing the generally successful use of rituximab in patients with dermatomyositis or polymyositis $[7,12,16$, $28,53,62,66]$.

\section{Antiphospholipid syndrome}

Antiphospholipid syndrome (APS), a rare disorder mostly affecting young adults, is defined by the presence of autoantibodies against phospholipids; the main clinical manifestations are venous or arterial thrombosis and obstetric complications, although the link between antiphospholipid antibodies and these clinical features has not been firmly established [39]. The traditional approach to treatment mainly involves the use of anticoagulation therapies. However, data indicating a link between raised circulating CD5+ B cells and high levels of antiphospholipid antibodies in APS patients [100] suggest that APS may be amenable to B cell-directed therapies.
To date, only a small number of case reports have been published which detail attempts to manage APS with rituximab. Three of these studies [5, 77, 94] reported successful clinical outcomes following rituximab therapy, while the other [4] reported only a limited effect of rituximab on thrombocytopenia and anticardiolipin antibodies in a patient with primary APS. Although the data are currently limited, the striking clinical successes seen in some patients suggest that pilot studies with rituximab in APS should be conducted in the near future.

\section{Still's disease}

Adult-onset Still's disease (AOSD) is a systemic inflammatory disorder of unknown etiology. Traditional therapies include NSAIDs, corticosteroids, and-more recentlydisease-modifying anti-rheumatic drugs [47]. A number of trials have also been conducted with biologic agents (including TNF inhibitors), with some promising results [32].

One case report was published recently that described the successful use of rituximab in a patient with AOSD [1]. This report, together with the author's unpublished observations of two patients with AOSD refractory to cytotoxic agents who benefited from repeated rituximab infusion therapy, suggests that rituximab may be a future treatment option for this disease.

Neurologic disorders

As reviewed recently by Finsterer [36], rituximab has been tested in a number of immune-mediated peripheral neuropathies with promising results. Its potential clinical utility in neurological diseases of the central nervous system such as multiple sclerosis (MS) remains to be explored. Encouragingly, pilot studies have shown that rituximab therapy results in partial depletion of $\mathrm{B}$ cells from the cerebrospinal fluid of patients with progressive MS [23, 63]. The results of the first Phase I and II trials of rituximab in progressive MS were presented recently [10, 44]. In the placebo-controlled Phase II study [44], involving 104 patients with relapsing remitting $\mathrm{MS}$, a single course of rituximab (two infusions of $1,000 \mathrm{mg}$ given 2 weeks apart) resulted in significantly fewer inflammatory brain lesions and relapses over the 6-month observation period compared with placebo. Rituximab treatment was reported to have been well tolerated.

\section{Conclusions}

Recent advances in our understanding of autoimmunity have opened up new avenues for exploring novel targeted 
therapies in a wide range of diseases. The role of B cells in many autoimmune disorders is now widely accepted, in many cases through the demonstration that $\mathrm{B}$ cell depletion using rituximab can often be very effective clinically. The potential utility of rituximab and other B cell-directed therapies is currently being studied in several of these diseases, including SLE, SS, and vasculitis. Although to date most of the findings have been encouraging, a significant proportion of the information derives from case reports and small case series. Together with the lack of randomized controlled trials in most of the diseases discussed in this review, it is likely that there has been a degree of positive reporting bias. Therefore, until large-scale clinical trial data are available, it would be prudent to proceed with caution regarding the use of rituximab outside its approved indications. Although rituximab tolerability was generally reported as favorable in most of the studies covered in this review, the true incidence of associated adverse events (e.g., serious infections, serum sickness-like reactions, and PML) will only become clear when larger numbers of patients have been treated in each disease entity. Important questions also remain regarding the optimal rituximab dosing modalities for each disease (for example, the dose and frequency of treatment, when re-treatment should be considered, and whether to use combination therapies). Nevertheless, based on the information published to date, it seems likely that B cell depletion therapy, using rituximab and-in the future-agents currently under development, will offer an effective new approach for the management of many of these burdensome and difficult-to-treat conditions.

Acknowledgments Writing assistance for this manuscript was provided by Genentech, Inc.

\section{References}

1. Ahmadi-Simab K, Lamprecht P, Jankowiak C, Gross WL (2006) Successful treatment of refractory adult onset Still's disease with rituximab. Ann Rheum Dis 65:1117-1118

2. Ahmadi-Simab K, Lamprecht P, Nolle B, Ai M, Gross WL (2005) Successful treatment of refractory anterior scleritis in primary Sjogren's syndrome with rituximab. Ann Rheum Dis 64:1087-1088

3. Ahmed A, Aggarwal A, Sharma D, Dave HP, Kinsella V, Rick ME et al (2004) Rituximab for treatment of refractory/relapsing thrombotic thrombocytopenic purpura (TTP). Am J Hematol 77:171-176

4. Ames PR, Tommasino C, Fossati G, Scenna G, Brancaccio V, Ferrara F (2007) Limited effect of rituximab on thrombocytopaenia and anticardiolipin antibodies in a patient with primary antiphospholipid syndrome. Ann Hematol 86:227-228

5. Anandacoomarasamy A, Gibson J, McGill N (2006) 'Cure' of life-threatening antiphospholipid syndrome with rituximab. Intern Med J 36:474-475

6. Anolik JH, Campbell D, Felgar RE, Young F, Sanz I, Rosenblatt $\mathrm{J}$ et al (2003) The relationship of Fc $\gamma$ RIIIa genotype to degree of
B cell depletion by rituximab in the treatment of systemic lupus erythematosus. Arthritis Rheum 48:455-459

7. Aranda-Pereira P, Melendez-Mercado C, Jaimes-Hernandez J (2007) Rituximab, alternative treatment in refractory idiopathic inflammatory myopathies. Ann Rheum Dis 66(Suppl. II):199 [Abstract No. THU0236]

8. Aries PM, Hellmich B, Voswinkel J, Both M, Nolle B, Holl-Ulrich K et al (2006) Lack of efficacy of rituximab in Wegener's granulomatosis with refractory granulomatous manifestations. Ann Rheum Dis 65:853-858

9. Arnold DM, Dentali F, Crowther MA, Meyer RM, Cook RJ, Sigouin C et al (2007) Systematic review: efficacy and safety of rituximab for adults with idiopathic thrombocytopenic purpura. Ann Intern Med 146:25-33

10. Bar-Or A, Calabresi P, Arnold D, Markowitz C, Shafer S, Kasper L et al (2007) A Phase I, open-label, multicenter study to evaluate the safety and activity of rituximab in adults with relapsingremitting multiple sclerosis (RRMS). In: American Academy of Neurology 59th Annual Meeting; Boston, April 28-May 5, 2007 [Abstract No. S.02.001]

11. Berentsen S, Ulvestad E, Gjertsen BT, Hjorth-Hansen H, Langholm R, Knutsen H et al (2004) Rituximab for primary chronic cold agglutinin disease: a prospective study of 37 courses of therapy in 27 patients. Blood 103:2925-2928

12. Blom M, van den Hoogen FH, Voermans NC, van Riel PL, Preijers FW, van Engelen BG et al (2007) Successful treatment with rituximab in patients with refractory inflammatory myopathies. Ann Rheum Dis 66(Suppl. II):202 [Abstract No. THU0245]

13. Braendstrup P, Bjerrum OW, Nielsen OJ, Jensen BA, Clausen NT, Hansen PB et al (2005) Rituximab chimeric anti-CD20 monoclonal antibody treatment for adult refractory idiopathic thrombocytopenic purpura. Am J Hematol 78:275-280

14. Brihaye B, Aouba A, Pagnoux C, Cohen P, Lacassin F, Guillevin L (2007) Adjunction of rituximab to steroids and immunosuppressants for refractory/relapsing Wegener's granulomatosis: a study on 8 patients. Clin Exp Rheumatol 25:S23-S27

15. Bryce AH, Dispenzieri A, Kyle RA, Lacy MQ, Rajkumar SV, Inwards DJ et al (2006) Response to rituximab in patients with type II cryoglobulinemia. Clin Lymphoma Myeloma 7:140-144

16. Chiappetta N, Steier J, Gruber B (2005) Rituximab in the treatment of refractory dermatomyositis. J Clin Rheum 11:264-266

17. Chow KV, Carroll R, Branley P, Nicholls K, Becker G, Hogan C (2007) Anti-CD20 antibody in thrombotic thrombocytopenic purpura refractory to plasma exchange. Intern Med J 37:329-332

18. Chowdhury F, Lawrence K, Baglin T, Perry D (2006) Rituximab failure in a patient with allo-FVIII inhibitor. $\mathrm{Br} \mathrm{J}$ Haematol 135:412

19. Christopher-Stine L, Plotz PH (2004) Myositis: an update on pathogenesis. Curr Opin Rheumatol 16:700-706

20. Clayton AR, Savage CO (2003) Production of antineutrophil cytoplasm antibodies derived from circulating B cells in patients with systemic vasculitis. Clin Exp Immunol 132:174-179

21. Cohen SB (2005) B-cell depletion for rheumatic diseases: where are we? MedGenMed 7:72

22. Cooper N, Stasi R, Cunningham-Rundles S, Feuerstein MA, Leonard JP, Amadori S et al (2004) The efficacy and safety of Bcell depletion with anti-CD20 monoclonal antibody in adults with chronic immune thrombocytopenic purpura. Br J Haematol 125:232-239

23. Cross AH, Stark JL, Lauber J, Ramsbottom MJ, Lyons JA (2006) Rituximab reduces B cells and T cells in cerebrospinal fluid of multiple sclerosis patients. J Neuroimmunol 180:63-70

24. Dass S, Bowman S, Vital EM, Ikeda K, Pease CT, Emery P (2007) Safety and efficacy of rituximab in Sjögren's syndrome: results of a randomised, placebo-controlled trial. Ann Rheum Dis 66(Suppl. II):70 [Abstract No. OP0061] 
25. de Vita S, Quartuccio L (2006) Treatment of rheumatoid arthritis with rituximab: an update and possible indications. Autoimmun Rev 5:443-448

26. Devauchelle-Pensec V, Pennec Y, Morvan J, Pers JO, Daridon C, Jousse-Joulin $S$ et al (2007) Improvement of Sjogren's syndrome after two infusions of rituximab (anti-CD20). Arthritis Rheum 57:310-317

27. Ding C, Jones G (2006) Belimumab (Human Genome Sciences/ Cambridge Antibody Technology/GlaxoSmithKline). Curr Opin Investig Drugs 7:464-472

28. Dinh HV, McCormack C, Hall S, Prince HM (2007) Rituximab for the treatment of the skin manifestations of dermatomyositis: a report of 3 cases. J Am Acad Dermatol 56:148-153

29. Dorner T, Kaufmann J, Wegener WA, Teoh N, Goldenberg DM, Burmester GR (2006) Initial clinical trial of epratuzumab (humanized anti-CD22 antibody) for immunotherapy of systemic lupus erythematosus. Arthritis Res Ther 8:R74

30. Edwards JC, Cambridge G (2001) Sustained improvement in rheumatoid arthritis following a protocol designed to deplete B lymphocytes. Rheumatology (Oxford) 40:205-211

31. Edwards JC, Cambridge G (2006) B-cell targeting in rheumatoid arthritis and other autoimmune diseases. Nat Rev Immunol 6:394-403

32. Efthimiou P, Paik PK, Bielory L (2006) Diagnosis and management of adult onset Still's disease. Ann Rheum Dis 65:564-572

33. Eisenberg R, Albert D (2006) B-cell targeted therapies in rheumatoid arthritis and systemic lupus erythematosus. Nat Clin Pract Rheumatol 2:20-27

34. Eriksson P (2005) Nine patients with anti-neutrophil cytoplasmic antibody-positive vasculitis successfully treated with rituximab. J Intern Med 257:540-548

35. Fakhouri F, Vernant JP, Veyradier A, Wolf M, Kaplanski G, Binaut $R$ et al (2005) Efficiency of curative and prophylactic treatment with rituximab in ADAMTS13-deficient thrombotic thrombocytopenic purpura: a study of 11 cases. Blood 106:19321937

36. Finsterer J (2005) Treatment of immune-mediated, dysimmune neuropathies. Acta Neurol Scand 112:115-125

37. Fox RI (2005) Sjogren's syndrome. Lancet 366:321-331

38. Fox RI (2007) FDA alert for rituximab in patients with systemic lupus erythematosus. Medscape Rheumatol

39. Franchini M (2006) The antiphospholipid syndrome: an update. Clin Lab 52:11-17

40. Gillis JZ, Dall'Era M, Gross A, Yazdany J, Davis J (2007) Six refractory lupus patients treated with rituximab: a case series. Arthritis Rheum 57:538-542

41. Gross JA, Dillon SR, Mudri S, Johnston J, Littau A, Roque R et al (2001) TACI-Ig neutralizes molecules critical for B cell development and autoimmune disease. impaired B cell maturation in mice lacking BLyS. Immunity 15:289-302

42. Gunnarsson I, Sundelin B, Jonsdottir T, Jacobson SH, Henriksson EW, van Vollenhoven RF (2007) Histopathologic and clinical outcome of rituximab treatment in patients with cyclophosphamide-resistant proliferative lupus nephritis. Arthritis Rheum 56:1263-1272

43. Hansen A, Lipsky PE, Dörner T (2005) Immunopathogenesis of primary Sjögren's syndrome: implications for disease management and therapy. Curr Opin Rheumatol 17:558-565

44. Hauser S, Waubant E, Arnold D, Vollmer T, Antel J, Fox R et al (2007) A Phase II randomized, placebo-controlled, multicenter trial of rituximab in adults with relapsing remitting multiple sclerosis (RRMS). In: American Academy of Neurology 59th annual meeting, Boston, April 28-May 5, 2007 [Abstract No. S.12.003]

45. Heidel F, Lipka DB, von Auer C, Huber C, Scharrer I, Hess G (2007) Addition of rituximab to standard therapy improves response rate and progression-free survival in relapsed or refrac- tory thrombotic thrombocytopenic purpura and autoimmune haemolytic anaemia. Thromb Haemost 97:228-233

46. Ioannou Y, Isenberg DA (2002) Current concepts for the management of systemic lupus erythematosus in adults: a therapeutic challenge. Postgrad Med J 78:599-606

47. Kadar J, Petrovicz E (2004) Adult-onset Still's disease. Best Pract Res Clin Rheumatol 18:663-676

48. Kalled SL (2006) Impact of the BAFF/BR3 axis on B cell survival, germinal center maintenance and antibody production. Semin Immunol 18:290-296

49. Kaushik VV, Reddy HV, Bucknall RC (2006) Successful use of rituximab in a patient with recalcitrant Churg-Strauss syndrome. Ann Rheum Dis 65:1116-1117

50. Keogh KA, Wylam ME, Stone JH, Specks U (2005) Induction of remission by B lymphocyte depletion in eleven patients with refractory antineutrophil cytoplasmic antibody-associated vasculitis. Arthritis Rheum 52:262-268

51. Keogh KA, Ytterberg SR, Fervenza FC, Carlson KA, Schroeder DR, Specks U (2006) Rituximab for refractory Wegener's granulomatosis: report of a prospective, open-label pilot trial. Am J Respir Crit Care Med 173:180-187

52. Koukoulaki M, Smith KG, Jayne DR (2006) Rituximab in Churg-Strauss syndrome. Ann Rheum Dis 65:557-559

53. Lambotte O, Kotb R, Maigne G, Blanc FX, Goujard C, Delfraissy JF (2005) Efficacy of rituximab in refractory polymyositis. J Rheumatol 32:1369-1370

54. Langford CA (2003) Wegener's granulomatosis: current and upcoming therapies. Arthritis Res Ther 5:180-191

55. Leandro MJ, Cambridge G, Edwards JC, Ehrenstein MR, Isenberg DA (2005) B-cell depletion in the treatment of patients with systemic lupus erythematosus: a longitudinal analysis of 24 patients. Rheumatology (Oxford) 44:1542-1545

56. Levine TD (2005) Rituximab in the treatment of dermatomyositis: an open-label pilot study. Arthritis Rheum 52:601-607

57. Lipsky PE (2001) Systemic lupus erythematosus: an autoimmune disease of B cell hyperactivity. Nat Immunol 2:764-766

58. Looney RJ (2006) B cell-targeted therapy for rheumatoid arthritis: an update on the evidence. Drugs 66:625-639

59. Looney RJ, Anolik JH, Campbell D, Felgar RE, Young F, Arend LJ et al (2004) B cell depletion as a novel treatment for systemic lupus erythematosus: a phase I/II dose-escalation trial of rituximab. Arthritis Rheum 50:2580-2589

60. Maloney DG, Grillo-López AJ, White CA, Bodkin D, Schilder RJ, Neidhart JA et al (1997) IDEC-C2B8 (Rituximab) anti-CD20 monoclonal antibody therapy in patients with relapsed low-grade non-Hodgkin's lymphoma. Blood 90:2188-2195

61. Mantadakis E, Danilatou V, Stiakaki E, Kalmanti M (2004) Rituximab for refractory Evans syndrome and other immune-mediated hematologic diseases. Am J Hematol 77:303-310

62. Mok CC, Ho LY, To CH (2007) Rituximab for refractory polymyositis: an open-label pilot study. Ann Rheum Dis 66(Suppl II):216 [Abstract No. THU0292]

63. Monson NL, Cravens PD, Frohman EM, Hawker K, Racke MK (2005) Effect of rituximab on the peripheral blood and cerebrospinal fluid B cells in patients with primary progressive multiple sclerosis. Arch Neurol 62:258-264

64. Ng KP, Cambridge G, Leandro M, Edwards JC, Ehrenstein MR, Isenberg DA (2007) B cell depletion therapy in patients with systemic lupus erythematosus: long term follow up and predictors of response. Ann Rheum Dis 66(Suppl. II):56 [Abstract No. OP0020]

65. Norton A, Roberts I (2006) Management of Evans syndrome. Br J Haematol 132:125-137

66. Noss EH, Hausner-Sypek DL, Weinblatt ME (2006) Rituximab as therapy for refractory polymyositis and dermatomyositis. J Rheumatol 33:1021-1026 
67. Oliveira B, Arkfeld DG, Weitz IC, Shinada S, Ehresmann G (2007) Successful rituximab therapy of acquired factor VIII inhibitor in a patient with rheumatoid arthritis. J Clin Rheumatol 13:89-91

68. Omdal R, Wildhagen K, Hansen T, Gunnarsson R, Kristoffersen G (2005) Anti-CD20 therapy of treatment-resistant Wegener's granulomatosis: favourable but temporary response. Scand J Rheumatol 34:229-232

69. Ozdogu H, Boga C, Kizilkilic E, Yeral M, Kozanoglu I, Karatas M (2007) A dramatic response to rituximab in a patient with resistant thrombotic thrombocytopenic purpura (TTP) who developed acute stroke. J Thromb Thrombolysis 23:147-150

70. Patino W, Sarode R (2007) Successful repeat therapy with rituximab for relapsed thrombotic thrombocytopenic purpura. J Clin Apher 22:17-20

71. Penalver FJ, Jimenez-Yuste V, Almagro M, Alvarez-Larran A, Rodriguez L, Casado M et al (2006) Rituximab in the management of chronic immune thrombocytopenic purpura: an effective and safe therapeutic alternative in refractory patients. Ann Hematol 85:400-406

72. Perrotta AL (2006) Re-treatment of chronic idiopathic thrombocytopenic purpura with rituximab: literature review. Clin Appl Thromb Hemost 12:97-100

73. Pijpe J, van Imhoff GW, Spijkervet FK, Roodenburg JL, Wolbink GJ, Mansour K et al (2005) Rituximab treatment in patients with primary Sjogren's syndrome: an open-label phase II study. Arthritis Rheum 52:2740-2750

74. Reddy PS, Deauna-Limayo D, Cook JD, Ganguly SS, Blecke C, Bodensteiner DC et al (2005) Rituximab in the treatment of relapsed thrombotic thrombocytopenic purpura. Ann Hematol 84:232-235

75. Rieger M, Mannucci PM, Kremer Hovinga JA, Herzog A, Gerstenbauer G, Konetschny C et al (2005) ADAMTS13 autoantibodies in patients with thrombotic microangiopathies and other immunomediated diseases. Blood 106:1262-1267

76. Ring T, Kallenbach M, Praetorius J, Nielsen S, Melgaard B (2006) Successful treatment of a patient with primary Sjogren's syndrome with Rituximab. Clin Rheumatol 25:891-894

77. Rubenstein E, Arkfeld DG, Metyas S, Shinada S, Ehresmann S, Liebman HA (2006) Rituximab treatment for resistant antiphospholipid syndrome. J Rheumatol 33:355-357

78. Sabahi R, Anolik JH (2006) B-cell-targeted therapy for systemic lupus erythematosus. Drugs 66:1933-1948

79. Sánchez-Cano D, Callejas-Rubio JL, Rios-Fernández R, OrtegoCenteno N (2007) Use of rituximab in Wegener's granulomatosis: comment on the article by Wong. Nephrol Dial Transplant 22:958-959

80. Sansonno D, de Re V, Lauletta G, Tucci FA, Boiocchi M, Dammacco F (2003) Monoclonal antibody treatment of mixed cryoglobulinemia resistant to interferon alpha with an anti-CD20. Blood 101:3818-3826

81. Schollkopf C, Kjeldsen L, Bjerrum OW, Mourits-Andersen HT, Nielsen JL, Christensen BE et al (2006) Rituximab in chronic cold agglutinin disease: a prospective study of 20 patients. Leuk Lymphoma 47:253-260

82. Scully M, Cohen H, Cavenagh J, Benjamin S, Starke R, Killick S et al (2007) Remission in acute refractory and relapsing thrombotic thrombocytopenic purpura following rituximab is associated with a reduction in IgG antibodies to ADAMTS-13. Br J Haematol 136:451-461

83. Seror R, Sordet C, Guillevin L, Hachulla E, Masson C, Ittah M et al (2007) Tolerance and efficacy of rituximab and changes in serum B cell biomarkers in patients with systemic complications of primary Sjogren's syndrome. Ann Rheum Dis 66:351-357

84. Sfikakis PP, Boletis JN, Lionaki S, Vigklis V, Fragiadaki KG, Iniotaki A et al (2005) Remission of proliferative lupus nephritis following B cell depletion therapy is preceded by down-regula- tion of the T cell costimulatory molecule CD40 ligand: an openlabel trial. Arthritis Rheum 52:501-513

85. Smith KG, Jones RB, Burns SM, Jayne DR (2006) Long-term comparison of rituximab treatment for refractory systemic lupus erythematosus and vasculitis: remission, relapse, and re-treatment. Arthritis Rheum 54:2970-2982

86. Sperr WR, Lechner K, Pabinger I (2007) Rituximab for the treatment of acquired antibodies to factor VIII. Haematologica 92:66-71

87. Stasi R, Pagano A, Stipa E, Amadori S (2001) Rituximab chimeric anti-CD20 monoclonal antibody treatment for adults with chronic idiopathic thrombocytopenic purpura. Blood 98:952-957

88. Stasi R, Stipa E, Del Poeta G, Amadori S, Newland AC, Provan D (2006) Long-term observation of patients with anti-neutrophil cytoplasmic antibody-associated vasculitis treated with rituximab. Rheumatology (Oxford) 45:1432-1436

89. Steinfeld SD, Tant L, Burmester GR, Teoh NK, Wegener WA, Goldenberg DM et al (2006) Epratuzumab (humanised antiCD22 antibody) in primary Sjögren's syndrome: an open-label phase I/II study. Arthritis Res Ther 8:R129

90. Steinfeld SD, Youinou P (2006) Epratuzumab (humanised antiCD22 antibody) in autoimmune diseases. Expert Opin Biol Ther 6:943-949

91. Tamura N, Matsudaira R, Hirashima M, Ikeda M, Tajima M, Nawata $\mathrm{M}$ et al (2007) Two cases of refractory Wegener's granulomatosis successfully treated with rituximab. Intern Med 46:409-414

92. Tokunaga M, Saito K, Kawabata D, Imura Y, Fujii T, Nakayamada $S$ et al (2007) Efficacy of rituximab (anti-CD20) for refractory systemic lupus erythematosus involving the central nervous system. Ann Rheum Dis 66:470-475

93. Touma Z, Sayad J, Arayssi T (2006) Successful treatment of Sjogren's syndrome with rituximab. Scand J Rheumatol 35:323-325

94. Trappe R, Loew A, Thuss-Patience P, Dorken B, Riess H (2006) Successful treatment of thrombocytopenia in primary antiphospholipid antibody syndrome with the anti-CD20 antibody rituximab-monitoring of antiphospholipid and anti-GP antibodies: a case report. Ann Hematol 85:134-135

95. Vigna-Perez M, Hernandez-Castro B, Paredes-Saharopulos O, Portales-Perez D, Baranda L, Abud-Mendoza C et al (2006) Clinical and immunological effects of Rituximab in patients with lupus nephritis refractory to conventional therapy: a pilot study. Arthritis Res Ther 8:R83

96. Weng WK, Levy R (2003) Two immunoglobulin G fragment C receptor polymorphisms independently predict response to rituximab in patients with follicular lymphoma. J Clin Oncol 21:3940-3947

97. Wiik A (2003) Autoantibodies in vasculitis. Arthritis Res Ther 5:147-152

98. Wong CF (2007) Rituximab in refractory antineutrophil cytoplasmic antibody-associated vasculitis: what is the current evidence? Nephrol Dial Transplant 22:32-36

99. Yomtovian R, Niklinski W, Silver B, Sarode R, Tsai HM (2004) Rituximab for chronic recurring thrombotic thrombocytopenic purpura: a case report and review of the literature. Br J Haematol 124:787-795

100. Youinou P, Renaudineau Y (2004) The antiphospholipid syndrome as a model for B cell-induced autoimmune diseases. Thromb Res 114:363-369

101. Zaja F, de Vita S, Mazzaro C, Sacco S, Damiani D, de Marchi G et al (2003) Efficacy and safety of rituximab in type II mixed cryoglobulinemia. Blood 101:3827-3834

102. Zaja F, Vianelli N, Battista M, Sperotto A, Patriarca F, Tomadini $\mathrm{V}$ et al (2006) Earlier administration of Rituximab allows higher rate of long-lasting response in adult patients with autoimmune thrombocytopenia. Exp Hematol 34:571-572

103. Zhang Z, Bridges SL Jr (2001) Pathogenesis of rheumatoid arthritis. Role of B lymphocytes. Rheum Dis Clin North Am 27:335-353 